\title{
THE WORKING CAPITAL MANAGEMENT MODEL IN AGRICULTURAL BUSINESS
}
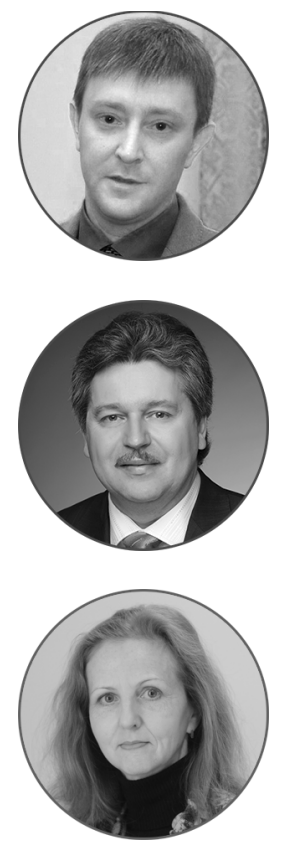

\section{Article history:}

Received 27 July 2018

Received in revised form

2 August 2018

Accepted 23 August 2018

Translated 9 November 2018

Available online 24 December 2018

JEL classification: M11

Keywords: agricultural business, agricultural policy, working capital, financial needs, operational management

\section{Denis Yu. SAMYGIN}

Penza State University, Penza, Russian Federation

vekont82@mail.ru https://orcid.org/0000-0002-5715-1227

\section{Corresponding author}

\section{Sergei M. IMYAREKOV}

Saransk Cooperative Institute, Branch of Russian University of Cooperation, Saransk, Republic of Mordovia, Russian Federation simyarekov@yandex.ru https://orcid.org/0000-0002-1752-9731

\section{Elena N. STEPASHKINA}

National Research Ogarev Mordovia State University, Saransk, Republic of Mordovia, Russian Federation s558456@mail.ru

\begin{abstract}
Subject The article discusses the management of current financial needs agricultural producers have. Objectives The research evaluates the current financial needs of agricultural producers and devises tools to coordinate the policy for managing the current assets and liabilities in agriculture at the regional level.

Methods The research employs methods of financial management and tools of econometric and statistical analysis, which are used to analyze and model the current financial needs of agricultural entities in the Penza Oblast.

Results We summarized and systematized financial methods for comprehensive operational management of current needs in agriculture. We used the specified financial management tools and grouped agricultural producers of the regions by type of the current assets and liabilities management policy. Doing so, we proved some aspects of the existing comprehensive operational management policy should be transformed and updated. We elaborated an econometric model reflecting the correlation of principal aspects of the policy concerning agricultural businesses. Describing the econometric model, we determine and coordinate strategic decisions on operational management of current financial needs in agriculture at the regional level.

Conclusions and Relevance Referring to the resultant functional relations, we can substantiate focal points to be addressed in improving the agricultural policy and raising additional financial resources for agriculture.
\end{abstract}

๑) Publishing house FINANCE and CREDIT, 2018

The editor-in-charge of this article was Irina M. Vechkanova

Authorized translation by Irina M. Vechkanova 
Currently, practices of project and financial management are reaching new horizons in Russia. As the legislative and regulatory framework gets more refined and updated, these practices are implemented by governmental authorities charged with management and regulation of national economic sectors. Agriculture is of special importance in this case so as to observe and pursue the national food security.

The robust legislative mechanism has been developed for the recent decade to move the agricultural business forward. It suffices to mention the priority national project, The Development of Agro-Industrial Complex, Federal Law, On Development of Agriculture, of 29 December 2006 № 264-Ф3, Food Security Doctrine, 2013-2020 National Program for Agricultural Development and Regulation of Markets of Agricultural Production, Resources and Food. The documents and other ones are intended to comfort the agricultural business.

The above documents emphasize agricultural production should be technologically and technically upgraded. Relevant activities are conducted to support the construction of new farms, greenhouses, development and improvement of farmlands, renewal of vehicles, equipment and agricultural machinery. Such investment projects and capital expenditures cannot be overestimated. They become a stepping stone for the future income, and reasonable source of discounted cash flows in a five-to-seven year time.

Unfortunately, sound investment policy in agricultural products overlooks the current operations of agricultural producers, which cannot but have certain difficulties. Current expenses are as important for production enterprises as capital expenditures. The production cycle of production enterprises includes the funding of inventories, tangible costs, payroll and social security charges, trade and other payables. As the government neglects the policy for managing the current financial needs in agriculture, the debtload of agricultural businesses grows, thereby preventing them from raising loans or State funds for their innovative development since the main fundraising mechanisms depend on financial and credit institutions.

${ }^{\dagger}$ For the source article, please refer to: Самыгин Д.Ю., Имяреков С.М., Степашкина Е.Н. Модель управления рабочим капиталом в аграрном бизнесе. Экономический анализ: теория и практика. 2018. Т. 17. № 10. С. 1951-1961.

URL: https://doi.org/10.24891/ea.17.10.1951
As the analysis of agricultural entities in the Penza Oblast shows, the agricultural entity's debtload exceeds its revenue, its fixed assets will be sufficient to satisfy only 30 percent of its current needs, while the debtload below the revenue raises this indicator up to 50 percent (Table 1).

Due to very scarce current assets, meager agricultural businesses have to take out short-term loans in order to construct current assets. That is the reason why their debtload with current liabilities accounts for almost 60 percent, while they are less than 30 percent in more financially sustainable entities. Under such circumstances, over 30 percent of agricultural businesses have a slim chance of securing long-term loans and improving their production capacities respectively.

Major agricultural firms set up their own model for managing net current assets [1]. The other ones lack funds from time to time to purchase materials and resources, pay for fuel and lubricants, create inventories, etc. [2]. This brings business performance results to nothing, intensifies the issue of deficit and shortage of resources and desynchronizes the outgoing and incoming flows of liquid assets. Agricultural producers have to increase their debts, disinvest and seek various financial aids [3].

In such circumstances, there should be an agricultural strategy in place to manage the current financial needs of agricultural producers. For this purposes, it is necessary to create a certain pool of available funds of agricultural producers in the regions, raise the standards of efficiency of financing and subsidizing sources [4].

Considering that the current financial needs are virtually the difference between current assets and accounts payable, indicating the agricultural producers' lack of credit resources [5], the agricultural policy is called to accelerate the turnover of circulating resources, choose the most appropriate approach to operational management of current assets and liabilities in the region [6] (Table 2).

The difference between readily available property and current sources of finance constitutes net working capital, which is measured using the technique depicted in Fig. 1.

In 2016, value of circulating resources owned by agricultural entities of the Penza Oblast equaled 25.67 percent of the annual turnover, or over RUB 10 billion. 
Only a portion of resources that the region's agricultural businesses posses are spent on current financial needs. The cash balance amounts to over RUB 3 billion.

As the analysis shows, agricultural entities of the region hold a sufficient amount of circulating resources, with 63 percent of them being spent on current operational needs of agricultural producers and other 37 percent forming freely available cash. In 2016, there was a 70 to 30 percent proportion respectively. Such current financial needs and resources give hope that the payment discipline will strengthen, expenses in the nearest future will be covered, minimum reserve stock and short-term financial investment will be formed. This highlights a most adequate balance of needs and financial sources.

Such a balance shall persist and be stable for a number of years so that an agricultural producer could be considered financially sustainable [7].

The ratio of financial sources of mobile assets is a key factor influencing the amount of net working capital of agricultural entities [8]. In this respect, the theory of financial management suggests observing the fundamental principle of operational life of assets matching their financial sources [9]. The principle implies that equity is a reasonable source feeding the constant minimum need in mobile assets. Shortterm loans sustain the other additional need in current assets, for example, those of seasonal nature [10]. It is necessary to compare the effectiveness of capital use and financial sustainability risk of agricultural businesses to reasonably choose sources for financing circulating resources of agricultural producers [11]. The factors underlie the policy for comprehensive operational management of financial needs. The policy pursues to maintain a certain level and composition of current assets, on one hand, and volume and effective structure of financial sources, on the other hand (Table 3).

Having analyzed the 2015-2016 data (Return on Assets, turnover period of mobile assets, etc.), we found out that many agricultural entities in the Penza Oblast tend to a moderate policy in managing their current assets. In the mean time, having analyzed a percentage of short-term loans in the total liabilities, we can report on an aggressive policy for managing the current liabilities, which immediately raises the effect of financial leverage. Fixed costs also include interests charged for utilizing loan resources, thereby intensifying operating leverage.
As indicated in the matrix for determining a type of current need management strategy (Fig. 2), the combination of moderate policy for managing current assets and aggressive policy for managing current liabilities enables us to describe the comprehensive policy of operational management at agricultural entities of the Penza Oblast.

To increase net working capital and financial sustainability, agricultural entities are advised to adopt a moderate policy for managing their current liabilities. This will curb the effect of financial leverage and boost a growth in the Weighted Average Cost of Capital (WACC).

Based on combined financial statements of agricultural entities in the Penza Oblast for 2015 through 2016, we conducted the statistical analysis of the current policy for comprehensive operational management using the grouping technique (Table 4, 5).

As the research shows, many business entities in the region tend to an aggressive policy for managing their current assets (almost 63 percent). The current assets out of total assets approximates 75 percent. Profitability of such entities is over 13 percent as compared with less than 1 percent in those entities having a conservative policy, and around 5 percent in entities with a moderate policy for managing current assets. Strengthening the current assets management policy increases the profitability and vice versa.

Over 64 percent of the region's agricultural entities are found to have a conservative policy for managing their current liabilities. Current liabilities account for 22 percent in such entities, while profitability is 8 percent. Entities with an aggressive policy (27.7 percent) have slightly lower profitability of 5.15 percent, but significantly higher turnover of circulating resources (1.71).

To combine the current assets management strategy and current liabilities management strategy as much as effectively, we set up the model reflecting the dependency of current financial needs policy on principal factors (Table 6). Profitability is deemed as the efficiency characteristics.

Conducting an econometric study into the current financial needs management strategy in agriculture of the Penza Oblast, we traced the high dependency of profitability both on elements of the current assets management policy and (92 percent) and current liabilities management policy (89 percent). Characteristics of the resultant models are evaluated to be adequate and significant. 
Having analyzed the current assets management model for elasticity, we determined that a 1-percent increase in the percentage of current assets raises profitability by 0.24 percent, while one additional turnover round adds 1.13 percent to profitability. Profitability grows only if equity rises. In the mean time, a percentage of current liabilities decreases the analyzable indicator by 0.04 percent.
The optimal combination of strategies for financing current needs is measured if profitability characteristics are given. The resultant values of indicators characterizing the policy for comprehensive operational management can be used to outline the uniform strategy for financial management of agricultural entities' current needs.

\section{Table 1}

Grouping of agricultural entities in the Penza Oblast by ratio of revenue and accounts payable

\begin{tabular}{llllll}
\hline $\begin{array}{l}\text { Groups of entities } \\
\text { by ratio of revenue } \\
\text { to accounts payable }\end{array}$ & $\begin{array}{l}\text { Percentage } \\
\text { of entities } \\
\text { in the group }\end{array}$ & $\begin{array}{l}\text { Average ratio of revenue } \\
\text { and accounts payable } \\
\text { in the group }\end{array}$ & $\begin{array}{l}\text { Percentage of current } \\
\text { liabilities }\end{array}$ & $\begin{array}{l}\text { Percentage } \\
\text { of fixed assets } \\
\text { in total assets }\end{array}$ & Percentage of equity \\
\hline Ratio below 1 & 21 & 0.5 & 58.9 & 28 & -42.9 \\
\hline Ratio above 1 & 79 & 5.94 & 29.7 & 47 & -19.5 \\
\hline
\end{tabular}

Source:Authoring

\section{Table 2}

Current financial needs in agricultural entities of the Penza Oblast for operations in 2015-2016

\begin{tabular}{llll}
\hline Metrics & $\mathbf{2 0 1 5}$ & $\mathbf{2 0 1 6}$ & Deviation \\
\hline Average revenue from sale, thousand RUB & $73,010.7$ & $107,221.3$ & $34,210.6$ \\
\hline Stocks of resources and finished products, thousand RUB & $11,794,813$ & $16,437,822$ & $4,643,009$ \\
\hline Right to claim receivables, thousand RUB & $10,648,877$ & $17,264,582$ & 661,5705 \\
\hline Trade payables, thousand RUB & $16,947,073$ & $26,666,400$ & $9,719,327$ \\
\hline Current financial needs, thousand RUB & $5,496,617$ & $7,036,004$ & $1,539,387$ \\
\hline Current financial needs, days & 75.29 & 65.62 & -9.67 \\
\hline Current financial needs, percent & 20.91 & 18.23 & -2.68 \\
\hline
\end{tabular}

Source: Authoring 
Table 3

Determining types of policy for current assets and current liabilities management in agricultural entities of the Penza Oblast in 2015-2016

\begin{tabular}{llll}
\hline Metric & $\mathbf{2 0 1 5}$ & $\mathbf{2 0 1 6}$ & Deviation \\
\hline Revenue from sales, thousand RUB & $26,283,866$ & $38,599,667$ & $12,315,801$ \\
\hline Net profit, thousand RUB & $3,612,597$ & $5,427,898$ & $1,815,301$ \\
\hline Current assets, thousand RUB & $25,723,156$ & $36,714,440$ & $10,991,284$ \\
\hline Fixed assets, thousand RUB & $37,109,051$ & $41,437,344$ & $4,328,293$ \\
\hline Total assets, thousand RUB & $62,832,207$ & $78,151,784$ & $15,319,577$ \\
\hline Equity, thousand RUB & $20,309,499$ & $23,447,656$ & $3,138,157$ \\
\hline Short-term loan, thousand RUB & $16,947,073$ & $26,666,400$ & $9,719,327$ \\
\hline Percentage of current assets in total assets & 40.94 & 46.98 & 6.04 \\
\hline Return on Assets, percent & 5.75 & 6.95 & 1.2 \\
\hline Turnover period of circulating resources, round & 1.02 & 1.05 & 0.03 \\
\hline Current equity, thousand RUB & $-16,799,552$ & $-17,989,688$ & $-1,190,136$ \\
\hline Percentage of short-term loans in total liabilities & 26.97 & 34.12 & 7.15 \\
\hline Type of current assets management policy & Moderate & Moderate & - \\
\hline Type of current liabilities management policy & Aggressive & Aggressive & - \\
\hline
\end{tabular}

Source: Authoring

\section{Table 4}

Grouping of agricultural entities by current assets management policy

\begin{tabular}{lllll}
\hline Group of entities & $\begin{array}{l}\text { Percentage of the } \\
\text { entities in the group }\end{array}$ & $\begin{array}{l}\text { Percentage of current } \\
\text { assets in total assets }\end{array}$ & Profitability, percent & $\begin{array}{l}\text { Turnover period of circulating } \\
\text { resources, round }\end{array}$ \\
\hline Conservative & 12.9 & 21.5 & 0.75 & 1.5 \\
\hline Moderate & 24.2 & 37.7 & 4.9 & 1.6 \\
\hline Aggressive & 62.9 & 74.6 & 13.5 & 0.7 \\
\hline
\end{tabular}

Source:Authoring 
Table 5

Grouping of agricultural entities by current liabilities management policy

\begin{tabular}{llllll}
\hline Group of entities & $\begin{array}{l}\text { Percentage } \\
\text { of entities } \\
\text { in the group }\end{array}$ & $\begin{array}{l}\text { Percentage of } \\
\text { current liabilities } \\
\text { in total assets }\end{array}$ & $\begin{array}{l}\text { Current equity, } \\
\text { thousand RUB }\end{array}$ & Profitability, percentage & $\begin{array}{l}\text { Turnover period } \\
\text { of circulating resources, } \\
\text { round }\end{array}$ \\
\hline Conservative & 64.3 & 21.9 & $-10,984,616$ & 7.75 & 0.86 \\
\hline Moderate & 8 & 42.2 & $-1,661,924$ & 6 & 0.9 \\
\hline Aggressive & 27.7 & 64.1 & $-5,276,282$ & 5.15 & 1.71 \\
\hline
\end{tabular}

Source:Authoring

Table 6

Functional dependence of profitability of agricultural producers in the Penza Oblast on aspects of the current financial needs management policy

\begin{tabular}{|c|c|c|c|c|c|}
\hline $\begin{array}{l}\text { Efficiency indicator } \\
Y\end{array}$ & $\begin{array}{l}\text { Aspects of current } \\
\text { financial needs } \\
\text { management policy }\end{array}$ & Model & $\begin{array}{l}\text { Regression } \\
\text { coefficient }\end{array}$ & $\begin{array}{l}\text { Fisher's exact test } \\
(\text { F-test }<0.05)\end{array}$ & $\begin{array}{l}\text { Student's t- } \\
\text { test } X 1 / X 2 \\
(P \text {-value }< \\
0.05)\end{array}$ \\
\hline \multirow[t]{2}{*}{ Profitability } & $\begin{array}{l}\text { Percentage of current } \\
\text { assets X1. } \\
\text { Turnover period of } \\
\text { circulating resources } \\
X 2\end{array}$ & $0.24 X 1+1.13 X 2-7.22$ & 0.92 & 0.002 & $0.0008 / 0.002$ \\
\hline & $\begin{array}{l}\text { Percentage of current } \\
\text { liabilities } X 1 \text {. } \\
\text { Current equity } X 2\end{array}$ & $\begin{array}{l}10.2-0.04 X 1+ \\
+0.0000024 X 2\end{array}$ & 0.89 & 0.003 & $0.004 / 0.01$ \\
\hline
\end{tabular}

Source:Authoring

Please cite this article as: Samygin D.Yu., Imyarekov S.M., Stepashkina E.N. The Working Capital Management Model in Agricultural 


\section{Figure 1}

The working capital measurement technique

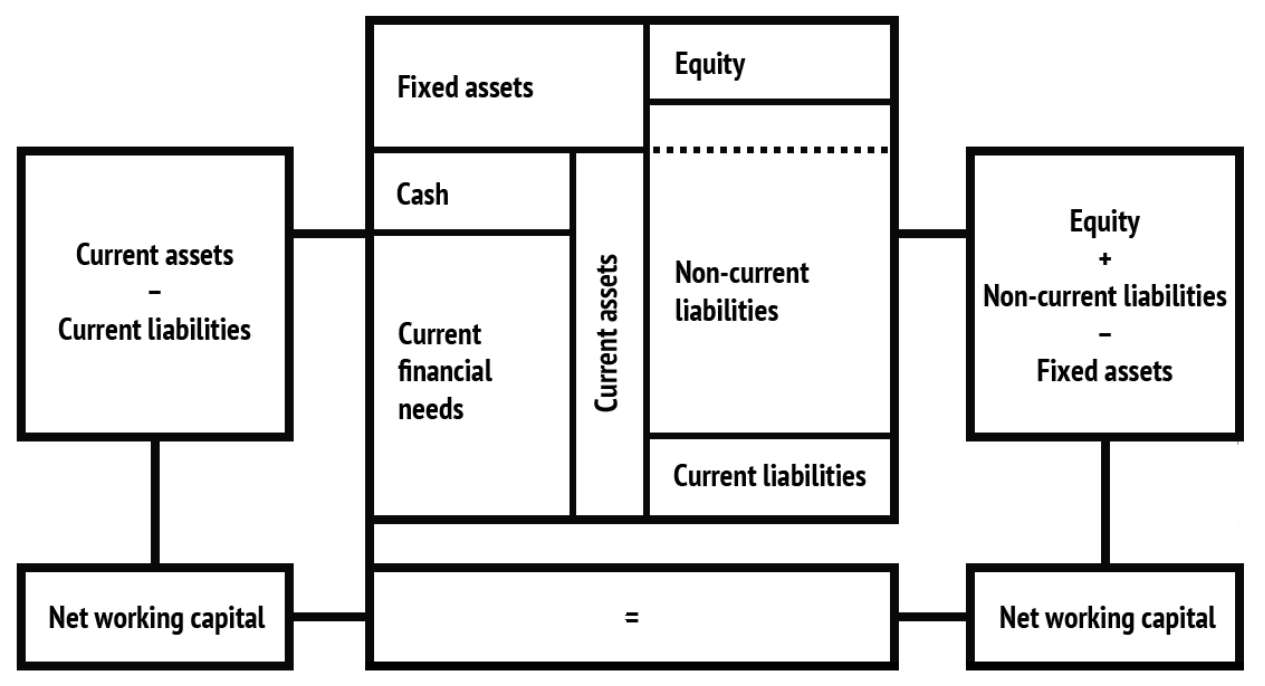

Source:Authoring

Figure 2

The matrix for choosing the policy for operational management of current assets and current liabilities

\begin{tabular}{|c|c|c|c|c|}
\hline & & \multicolumn{3}{|c|}{ Current assets management policy } \\
\hline & & Conservative & Moderate & Aggressive \\
\hline \multirow{3}{*}{$\begin{array}{l}\text { Current assets } \\
\text { management } \\
\text { policy }\end{array}$} & Aggressive & Inapplicable & Moderate policy & Aggressive policy \\
\hline & Moderate & Moderate policy & Moderate policy & Moderate policy \\
\hline & Conservative & Conservative policy & Moderate policy & Inapplicable \\
\hline
\end{tabular}

Source:Authoring

\section{Acknowledgments}

The article was supported by the Russian Foundation for Basic Research, project № 16-32-00015-ОГН.

\section{References}

1. Bespakhotnyi G.V. [Planning in agriculture - scientific support]. Ekonomika sel'skokhozyaistvennykh $i$ pererabatyvayushchikh predpriyatii = Economy of Agricultural and Processing Enterprises, 2017, no. 10, pp. 8-12. (In Russ.)

2. Davydova L.V., Il'minskaya S.A. [Policy for working capital management as part of the general financial strategy of the enterprise]. Finansy $i$ kredit = Finance and Credit, 2006, no. 15, pp. 5-11.

URL: https://cyberleninka.ru/article/v/politika-upravleniya-oborotnym-kapitalom-kak-chast-obscheyfinansovoy-strategii-predpriyatiya (In Russ.)

3. Baryshnikov N.G., Samygin D.Yu. [Solvency control in agriculture: Economic and statistical aspect (Case study: Penza region)]. Voprosy Statistiki, 2015, no. 1, pp. 65-76. URL: https://voprstat.elpub.ru/jour/article/view/183 (In Russ.)

Please cite this article as: Samygin D.Yu., Imyarekov S.M., Stepashkina E.N. The Working Capital Management Model in Agricultural Business. Digest Finance, 2018, vol. 23, iss. 4, pp. 395-402. https://doi.org/10.24891/df.23.4.395 
4. Serghiescu L., Văidean V.-L. Determinant Factors of the Capital Structure of a Firm: An Empirical Analysis. Procedia Economics and Finance, 2014, vol. 15, pp. 1447-1457. URL: https://doi.org/10.1016/S2212-5671(14)00610-8

5. Lazareva N.A. [The Analysis of Elements of Own Capital by Means of the Computer Finekanaliz Program]. Aktual'nye problemy ekonomiki, sotsiologii i prava = Urgent Issues of Economics, Sociology and Law, 2015, no. 2, pp. 118-121. (In Russ.)

6. Bonini S., Alkan S., Salvi A. The Effects of Venture Capitalists on the Governance of Firms. Corporate Governance: An International Review, 2012, vol. 20, iss. 1, pp. 21-45. URL: http://dx.doi.org/10.1111/j.1467-8683.2011.00888.x

7. Benjamin C., Phimister E. Does Capital Market Structure Affect Farm Investment? A Comparison Using French and British Farm-Level Panel Data. American Journal of Agricultural Economics, 2002, vol. 84, iss. 4, pp. 1115-1129. URL: https://doi.org/10.1111/1467-8276.00372

8. Walker R.M., Lee M.J., James O., Ho S.M.Y. Analyzing the Complexity of Performance Information Use: Experiments with Stakeholders to Disaggregate Dimensions of Performance, Data Sources, and Data Types. Public Administration Review, 2018, vol. 78, iss. 1, pp. 1-12. URL: https://doi.org/10.1111/puar.12920

9. Shin H., Soenen L. Efficiency of Working Capital and Corporate Profitability. Financial Practice and Education, 1998, vol. 8, iss. 2, pp. 37-45.

10. Deloof M. Does Working Capital Management Affect Profitability of Belgian Firms? Journal of Business Finance and Accounting, 2003, vol. 30, iss. 3-4, pp. 573-587. URL: https://doi.org/10.1111/1468-5957.00008

11. Teplykh G.V., Galimardanov A.Sh. [Modeling of innovative investment in Russian regions]. Prikladnaya ekonometrika = Applied Econometrics, 2017, vol. 46, pp. 104-125. (In Russ.)

\section{Conflict-of-interest notification}

We, the authors of this article, bindingly and explicitly declare of the partial and total lack of actual or potential conflict of interest with any other third party whatsoever, which may arise as a result of the publication of this article. This statement relates to the study, data collection and interpretation, writing and preparation of the article, and the decision to submit the manuscript for publication. 